Studia Judaica 22 (2019), nr 2 (44), s. 305-328

doi:10.4467/24500100STJ.19.014.12397

Sławomir Buryła (iD https://orcid.org/0000-0001-9838-0467

\title{
Marzec a Zagłada - płaszczyzny spotkania
}

\author{
MARCH 1968 AND THE SHOAH: THE COMMON GROUNDS
}

\begin{abstract}
This article is a synthetic study on major issues related to the events of 1968 in Poland and their similarity to the atmosphere at the time of the Holocaust. The author presents analogies and differences between the antisemitic campaign of 1968 and the Shoah, analyzing: (1) the rhetoric of journalistic texts and political speeches; (2) works of art; (3) literary representations; and (4) memories of the victims. The main material for the analysis consists of prose texts-novels and short stories-written both in the late 1960s and after the political transformation of 1989.
\end{abstract}

Keywords: totalitarianism, 1968, Holocaust, literature, caricature, antisemitism.

Słowa kluczowe: totalitaryzm, rok 1968, Holokaust, literatura, karykatura, antysemityzm.

„Polski rok 1968” i Holokaust ${ }^{1}$ to odmienne wydarzenia historyczne, fakty z przeszłości mające własną dynamikę, osadzone w różnych kontekstach historycznych - nieporównywalne w aspekcie zdarzeń, liczb, realiów społecznych, a nawet postaw ludzkich. W jakich zatem obszarach uprawomocnione jest mówienie o Marcu jako o zjawisku odsyłającym do Zagłady?

${ }^{1}$ Sięgając po formułę „polski rok 1968”, nawiązuję do określenia użytego przez Jerzego Eislera - zob. Jerzy Eisler, Polski rok 1968, Warszawa 2006. Należy zaznaczyć, że termin „Holokaust” pojawił się w latach sześćdziesiątych, po procesie Eichmanna. Zob. Monika Adamczyk-Garbowska, Henryk Duda, Terminy „Holocaust”, ,Zagłada” $i$,Szoa” oraz ich konotacje leksykalno-kulturowe w polszczyźnie potocznej i dyskursie naukowym, „Pro Memoria” (2007), nr 25, s. 65-74. 
Płaszczyzny interferencji i spotkania obu pojęć wyznaczają tu: (1) retoryka tekstów publicystycznych i wystąpień politycznych, (2) przestrzeń dzieł sztuki, (3) obrazy literackie oraz (4) pamięć ofiar. W ich obrębie możemy poszukiwać śladów doświadczeń holokaustowych, przebłysków (powidoków?) rzeczywistości wojennej, ale nie jej dokładnych odwzorowań.

Nim przejdziemy do omówienia zasygnalizowanej tematyki, wypada poczynić dwie uwagi ogólniejszej natury. Po pierwsze, w połowie lat sześćdziesiątych XX w. nie chodziło o przeprowadzenie dyskusji nad tym, czym była Zagłada w dziejach Polski. Nie toczono przecież debaty o przebiegu eksterminacji Żydów, sposobie dokonanej zbrodni, skali ofiar, metodzie przeprowadzenia ludobójczego mordu ani - tym bardziej - o roli, jaką ewentualnie odegrali w nim obywatele polscy. Problemem był nie tyle los Żydów w czasie wojny, ile losy oraz trudne wybory Polaków. Z punktu widzenia marcowych polityków, publicystów i powolnych im historyków, ale też niektórych artystów, główną ofiarą genocydu dokonanego przez hitlerowców była ludność polska - etniczni Polacy. Z jednej strony zatem zacierano żydowskość Szoah (co zresztą było stałą tendencją w $\mathrm{PRL}^{2}$ ), a z drugiej eksponowano rozmiary czynu zbrojnego i martyrologię narodu polskiego. Marzec - obok czasów stalinowskich - w najbardziej jaskrawy sposób manipulował pamięcią o wojnie i Zagładzie. Holokaust stał się w latach sześćdziesiątych XX w. przedmiotem skrajnej instrumentalizacji.

Po drugie, pojęcie Zagłady, pojawiające się w tytule tego szkicu, miało wówczas odmienny zakres znaczeniowy niż obecnie. Eksterminacja Żydów w oficjalnym dyskursie pojmowana była w latach sześćdziesiątych XX w. $\mathrm{z}$ jednej strony jako fragment eksterminacji narodu polskiego, $\mathrm{z}$ drugiej - jako część walki międzynarodowego imperializmu z klasą robotniczą ${ }^{3}$. Co równie istotne - i od czego nie można abstrahować, mówiąc o atmosferze Marca '68 - ówczesne społeczeństwo miało nie tylko mniejszą, ale i często wypaczoną wiedzę na temat Holokaustu. Na to nakładała się sieć resentymentów i urazów (o skali znacznie większej niż obecnie), a także (z reguły niewypowiedziane) poczucie winy.

2 Początki i główne wymiary ideologicznego widzenia Holokaustu w czasach Polski Ludowej dobrze określa monografia Zofii Wóycickiej - zob.: Zofia Wóycicka, Przerwana żałoba. Polskie spory wokót pamięci nazistowskich obozów koncentracyjnych i zagłady 1944-1950, Warszawa 2009.

3 Tamże. 


\section{Tło: nacjonalistyczna legitymizacja władzy i sztuka narodowa}

Tropienie związków Marca '68 i Zagłady nie może się odbywać w politycznej i historycznej próżni. Apogeum rządów Władysława Gomułki przypada na szczytowy okres nacjonalistycznej legitymizacji komunizmu ${ }^{4}$. To moment triumfu publicystyki płk. Zbigniewa Załuskiego oraz koncepcji kina narodowego. Siedem polskich grzechów głównych czy Przepustka do historii wzmacniały i uzasadniały wszystkie te tendencje w kulturze, sztuce oraz świadomości, budowały antyakowską i antyinteligencką legendę, dowartościowując członków Gwardii Ludowej oraz Batalionów Chłopskich $^{5}$. Przykładem tych tendencji jest porucznik „Kruk” z Barw walki Mieczysława Moczara. Ireneusz Siwiński interpretował kinową wersję Barw walki w kontekście potrzeby zbudowania własnego mitu - ludowego - dla którego wszakże koniecznym punktem odniesienia pozostawała „sprawa akowska”.

Pułkownik Załuski widział rolę kultury jako pierwiastka wzmacniającego postawy obronne w społeczeństwie, restytuującego ducha narodowego. Miało to służyć patriotycznemu wychowaniu młodego pokolenia. Aby spełniać swoją funkcję, kultura musiała zostać zmilitaryzowana - nasycona treściami wojennymi i wojskowymi. W tej koncepcji „wojsko staje się nie tylko nośnikiem patriotyzmu, ale także nośnikiem kultury"7. Duch armii miał rzutować na proces wychowania młodego pokolenia, jak też określać cele prowadzonej przez państwo polityki historycznej. W publicystyce i koncepcjach ideowych Załuskiego rolę pierwszoplanową odgrywał żołnierski mundur, taki też system wartości i styl życia. Tragedia ludności cywilnej nie znajdowała większego uznania w oczach autora Przepustki do historii. Naród cementowały wielkie czyny zbrojne i gotowość do ich podjęcia.

Pokrewni ideowo Załuskiemu „partyzanci” przekształcili „ideologie komunizmu w kierunku przyswojenia rodzimych i zakorzenionych w wielu środowiskach wątków nacjonalistyczno-plebejskich", w nowym kontekście

${ }^{4}$ Zob. Marcin Zaremba, Komunizm, legitymizacja, nacjonalizm. Nacjonalistyczna legitymizacja władzy komunistycznej w Polsce, Warszawa 2005.

${ }_{5}$ Zbigniew Załuski, Siedem polskich grzechów głównych, Warszawa 1962; tenże, Przepustka do historii, Warszawa 1963.

${ }^{6}$ Ireneusz Siwiński, „Barwy walki” albo tęsknota za legenda, [w:] Syndrom konformizmu? Kino polskie lat sześćdziesiątych, red. Tadeusz Miczka, Alina Madej, Katowice 1994, s. $136-137$.

${ }^{7}$ Lukasz Polniak, Patriotyzm wojskowy w PRL w latach 1956-1970, Warszawa 2011, s. 225 . 
zaadaptowanych do wojennych i powojennych dziejów Polski ${ }^{8}$. Wspólnie z płk. Załuskim Mieczysław Moczar i jego ludzie apoteozowali potęgę militarną i odwagę polskiego żołnierza (szczególnie akcentując czyn zbrojny rodzimych komunistów). W postępującym sukcesywnie uwzniośleniu polskiego poświęcenia i ofiary nie było już miejsca na doświadczenie żydowskie. Nawet jeśli można było usłyszeć o losie Żydów, to na tle losu polskiego będącego zawsze na pierwszym planie.

W latach sześćdziesiątych XX w. kino, plakat, powieść, pamiętniki, materiały wspomnieniowe i artykuły dziennikarskie zamieszczane w codziennej prasie realizowały na różne sposoby wytyczne tzw. patriotyzmu wojskowego. Twórca tego pojęcia widzi w nim „próbę oparcia modelu patriotyzmu na upamiętnieniu bohaterstwa wojennego, walce z Niemcami oraz polityczno-militarnym sojuszu z ZSRR"

Wspólnotę pamięci ze społeczeństwem buduje się w epoce gomułkowskiej na wyidealizowanym obrazie „naszego wojska” i „naszego narodu”. Żywy ogień Władysława Machejka, Łuny w Bieszczadach Jana Gerharda oraz Barwy walki Mieczysława Moczara - zgodnie z duchem rządów Władysława Gomułki - do tego stopnia wypełniono polską perspektywą widzenia wojny, polskim cierpieniem i bohaterstwem, że nie zostawało miejsca na jakiekolwiek inne zachowania. Takie ujęcie okupacji oraz wojny - w literaturze i kinie - zarówno realizowało oczekiwania państwowe, jak i zaspokajało stereotypy oraz zapotrzebowanie społeczne.

Wojenne wspomnienia zawodowych pisarzy z czasów II wojny światowej i amatorskich autorów były aktywnie wspierane przez nurt w kinie polskim, który Tadeusz Lubelski określił mianem „narodowo-kombatanckiego"10. Jego czołowymi postaciami byli Jerzy Passendorfer, Ewa i Czesław Petelscy, Bogdan Poręba.

Ujawniona w połowie lat sześćdziesiątych XX w. nacjonalistyczna retoryka stanowiła zapowiedź propagandy marcowej, wykuwając dla niej odpowiedni język, ale i schematy myślenia oraz konteksty interpretacyjne. „Patriotyczny terror” natomiast to podstawowy kontekst dla postrzegania Zagłady i relacji polsko-żydowskich przez różne komunistyczne frakcje,

${ }^{8}$ Andrzej Friszke, Przystosowanie i opór. Studia z dziejów PRL, Warszawa 2007, s. 132.

${ }^{9}$ Zob. Polniak, Patriotyzm wojskowy w PRL..., s. 41. Przedstawienia tej tematyki w kinie omawia Piotr Zwierzchowski, Kino nowej pamięci. Obraz II wojny światowej w kinie polskim lat 60., Bydgoszcz 2013.

${ }^{10}$ Zob. Tadeusz Lubelski, Historia kina polskiego. Twórcy, filmy, konteksty, Katowice 2009, s. 238-246. 
marcowych publicystów, zwykłych obywateli PRL, lecz także niektóre elity artystyczne (np. przez filmowców czy rysowników).

Znamiennym przykładem unarodowiania historii są przypadające w tym czasie obchody 25. rocznicy wybuchu powstania w getcie warszawskim. Już wcześniej wiele uczyniono dla polonizacji tego wydarzenia ${ }^{11}$. Centralne obchody odbyły się 18 i 21 kwietnia. Ich znakiem rozpoznawczym może być przemówienie wygłoszone przez Kazimierza Rusinka na uroczystej akademii. Wiceminister kultury i sztuki odróżnił antysemityzm i antysyjonizm, łącząc ten ostatni z kapitalizmem. Antysemityzm starał się równoważyć antypolonizmem w kręgach Zachodu, a obwinianie Polaków o obojętność wobec Zagłady - oskarżeniami „przedstawicieli Światowego Kongresu Żydów o nieudzielanie pomocy ginącym rodakom"12. Rusinek odbierał wyjątkowość żydowskiemu doświadczeniu, czyniąc je - zgodnie z marksistowskimi dyrektywami - fragmentem cierpienia polskiego i proletariackiego.

\section{Pretekst: „encyklopedyści” i pominięte cierpienia}

Sprawa „encyklopedystów” - jedna z najbardziej znanych z Marca '68 - odsyła wprost do kontekstu zagładowego. Spór dotyczył hasła „obozy koncentracyjne". W tle jednak były upowszechniane przez ekipę Gomułki i Moczara hasło patriotyzmu wojskowego oraz idea bohaterskiej walki narodu polskiego z okupantem połączona z wizją wyjątkowych cierpień, jakich doznali Polacy w czasie wojny. Od początku w dyskusji zaznaczyły się rozbieżności, których nie można było pogodzić. Henryk Grynberg w książce o Adamie Brombergu pisze z charakterystyczną dla siebie wyrazistością myślową i stylistyczną:

Ignorując zupełnie wyjaśnienie, że z braku późniejszych opracowań encyklopedia brała pod uwagę historie miejscowości tylko do 1939 roku, moczarowcy oburzali się, że w hasłach miast i miasteczek nie ma wzmianek o zwycięstwie partyzantów w Świńskiej Górze, o starciach, potyczkach i stratach w Biłgoraju, Blachowni, Bliżynie, Bochni, Bochotnicy [...] i o krwawych pacyfikacjach - w odwecie za te potyczki i starcia. Nie mieli pretensji, że encyklopedia nie wspominała o dużo tragiczniejszym losie Żydów, którzy stanowili większość ludności tych miasteczek. [...] Nie narzekali również na brak wzmianek o akcjach żydowskich oddziałów na Lubelszczyźnie ${ }^{13}$.

${ }^{11}$ Zob. Renata Kobylarz, Walka o pamięć. Polityczne aspekty obchodów rocznicy powstania w getcie warszawskim 1944-1989, Warszawa 2009.

${ }_{12}$ Tamże, s. 207.

${ }^{13}$ Henryk Grynberg, Memorbuch, Warszawa 2000, s. 263. 
Punktem sporu okazało się hasło „obozy koncentracyjne” zamieszczone w ósmym tomie Wielkiej encyklopedii powszechnej PWN (WEP). Dokonano w nim rozróżnienia na obozy koncentracyjne i obozy zagłady. Te ostatnie - jak wskazywano - w 99 procentach przeznaczone były dla Żydów. Dziś trudno o jasną odpowiedź na pytanie, kto „wytypował hasło obozy koncentracyjne hitlerowskie [...] jako podstawę do akcji politycznej o jawnie antysemickim charakterze, wymierzonej w dawnych "puławian «"14.

Hasło z WEP, jak przyznaje Tadeusz Rutkowski, miało swoje wady. Zawyżono liczbę ofiar żydowskich (choć taki był mniej więcej stan ówczesnej wiedzy), w ogólnej liczbie tych ofiar nie uwzględniono ludzi, którzy zginęli w gettach i masowych egzekucjach na Wschodzie. „Decyzją co najmniej dyskusyjną okazało się [...] przyjęte założenie o niepublikowaniu informacji dotyczących dziejów danych miejscowości i regionów Polski w czasie II wojny światowej" ${ }^{15}$. Błędnie też podano i stale broniono stwierdzenia, iż wszystkie ośrodki zagłady znajdowały się na terenie ziem polskich ${ }^{16}$. Nie ulega jednak wątpliwości, że celem ataku na WEP nie było poprawienie błędów w - miejscami - dość niedbale przygotowanym haśle encyklopedycznym. Charakter i siła ataku miały przede wszystkim podtekst polityczny ${ }^{17}$. Niemniej jednak zredagowane bez należytej staranności hasło posłużyło moczarowcom do rozpoczęcia nagonki na redakcję WEP. Prowadzono ją pod szyldem marginalizowania martyrologii polskiej. Marcowa prasa oskarżała syjonistów - nieczujących więzi z polskością - że wkładają wiele wysiłku, by zakłamać dzieje Polski i Polaków, że nie powstrzymają się nawet przed wejściem w alians z elitami Niemiec Zachodnich, że na mocy układów i niejawnych knowań odsunęli od redagowania encyklopedii PWN rzetelnych badaczy $i$,tendencyjnie dobrali hasła z zakresu historii współczesnej lub ograniczyli ich treść pomijając to, co było niezgodne z syjonistyczną propagandą"18.

14 Tadeusz P. Rutkowski, Adam Bromberg $i$,encyklopedyści”. Kartka z dziejów inteligencji w PRL, Warszawa 2010, s. 193.

15 Tamże, s. 287.

16 Twierdzenie to jest prawdziwe, jeśli przyjmiemy, że - włączone bezpośrednio do Rzeszy - Chełmno znajdowało się na terenie Polski.

${ }^{17}$ Pisze Piotr Osęka: „Od początku staje się [...] jasne, że błędy popełnione przez redaktorów PWN miały być, według oskarżycieli, nie tyle skutkiem karygodnego nawet niechlujstwa, ile wynikiem politycznej dywersji”. Piotr Osęka, Marzec '68, Kraków 2008, s. 132.

${ }_{18}$ Tak referuje Anna Barbara Jarosz istotę retoryki marcowej wymierzonej w tzw. encyklopedystów - zob.: Anna Barbara Jarosz, Marzec w prasie, [w:] Marzec 1968. Trzydzieści lat później. T. 1: Referaty, red. Marcin Kula, Piotr Osęka, Marcin Zaremba, Warszawa 1998, s. 115 . 
Nowe hasło „obozy koncentracyjne” nie zawierało już podziału na obozy koncentracyjne i obozy zagłady. Dokonano też dookreślenia: „hitlerowskie". W nowym ujęciu lagry służyły biologicznemu wyniszczeniu przede wszystkim narodu polskiego, a eksterminację Żydów wymieniono na trzecim miejscu (po Polakach i jeńcach radzieckich).

Widząc w „syjonistach” wroga działającego na rzecz umniejszania cierpienia Polaków i odwołując się do bohaterskiej przeszłości narodu polskiego, komuniści wzmacniali identyfikację społeczeństwa $\mathrm{z}$ ich polityką. Tadeusz Rutkowski w najpełniejszym i najrzetelniejszym obecnie opracowaniu naukowym omawianych tu kwestii znakomicie ujmuje splot problemów towarzyszących sprawie „encyklopedystów”:

Ataki na autorów WEP i PWN wpisywały się w główne tezy „kampanii antysyjonistycznej”, stanowiąc jej cenne uzupełnienie poprzez odwołanie się do wrażliwości historycznej polskiego społeczeństwa, które w znacznym stopniu nie odreagowało jeszcze traumy II wojny światowej, pozbawione było także możliwości swobodnego wyrażania swoich emocji i upamiętniania poległych i pomordowanych. Nagłośnienie na Zachodzie antysemickiej nagonki w PRL, połączone z często niesprawiedliwym ocenianiem postawy Polaków wobec Żydów w czasie II wojny światowej, dawało propagandzie władz argumenty, odbierane ze zrozumieniem przez sporą część opinii publicznej ${ }^{19}$.

Ciekawym uzupełnieniem nie tyle sporu wokół omawianego hasła „obozy koncentracyjne hitlerowskie”, ile społecznego i politycznego kontekstu dyskusji o „encyklopedystach” jest wywód narratora Raportu $z$ Monachium Andrzeja Brychta. W jego ręce dostaje się praca profesora Carla Dietricha Polskie obozy koncentracyjne w świetle faktów (zachowuję oryginalną pisownię):

profesor doktor udowadnia, UDOWADNIA NAUKOWO niemieckim czytelnikom, że obóz koncentracyjny Auschwitz-Birkenau był obozem POLSKIM, założonym przez Polaków w celu wyniszczenia Żydów, leżał ten obóz przecież na polskim terenie, więc już to jest argumentem za tym przemawiającym, ponadto wiadomo wszystkim, że społeczeństwo polskie słynęło z piekielnie antysemickich nastrojów, ale ponieważ Polacy nie mają za grosz zmysłu organizacyjnego, poprosili Niemców o pomoc w OPRACOWANIU ORGANIZACYJNYM obozu, a Niemcy zrobili to, nie będąc wtajemniczeni przez Polaków co do właściwego przeznaczenia tej inwestycji ${ }^{20}$.

${ }^{19}$ Rutkowski, Adam Bromberg i „encyklopedyści”..., s. 289.

20 Andrzej Brycht, Raport z Monachium, wyd. 3, Warszawa 1968, s. 76. 
To bodaj jedyny raz, kiedy Andrzej Brycht wprowadza kontekst zagładowy w swoim tekście. Nie znajdziemy w przywołanym cytacie znamiennego dla marcowej nowomowy połączenia tematu żydowskiego i niemieckiego, ale jest poczucie niezawinionej winy, zamiany ról kata i ofiary. Niezależnie od tego, że stylizowany na dokument, niezwykle popularny wtedy utwór Brychta przeinacza fakty i manipuluje odbiorcą (stosując na przykład szantaż psychologiczny), ujawnia również wrażliwe punkty ówczesnej świadomości historycznej, ale i zawiera - odnotowywane już przez Tadeusza Rutkowskiego - niesprawiedliwe uproszczenia, jakie czasami pojawiały się w prasie zachodniej.

\section{Płaszczyzny przenikania: marcowi politycy i publicyści}

Najwcześniejszym politycznym śladem połączenia wojny sześciodniowej oraz dziejów współczesnego Izraela z Holokaustem była wypowiedź I Sekretarza KC PZPR na VI Kongresie Związków Zawodowych 19 czerwca 1967 r. Władysław Gomułka stwierdził wtedy, że „nie chce, aby w naszym kraju powstała 5-ta kolumna"21. Było to nawiązanie do najgorszych tradycji i najdrażliwszych punktów w polskim doświadczeniu historycznym - kolaboracji, jakiej dopuściła się mieszkająca w Polsce ludność niemiecka w momencie przekroczenia granicy przez hitlerowców. Gomułka zespolił problem niemiecki z kwestią żydowską, co stanie się wyróżnikiem kampanii antysemickiej w Marcu '68. Publicyści i politycy tego czasu prowadzili grę podobieństw i rozbieżności, w której w zaskakujący sposób przeciwieństwa spotykały się ze sobą - często na dziwacznych płaszczyznach. W tej grze element niemiecki (z gruntu zły) znajdował sprzymierzeńca w działaniach rządu izraelskiego i światowej diaspory żydowskiej. Swoim wystąpieniem Gomułka zainicjował dwa ważne tropy marcowej publicystyki: porównanie armii Izraela do hitlerowskiej oraz przywołanie poświęcenia, z jakim Polacy ratowali w czasie ostatniej wojny swoich żydowskich współobywateli ${ }^{22}$.

Stale obecne w prasie i radiu, akcentowane przez marcowych polityków porównanie Izraela z hitlerowską Rzeszą należy rozpatrywać na tle stopnia antyniemieckiego amoku, w jakim trwała władza. „Z tego okresu można przytoczyć niezliczoną liczbę przykładów - artykułów, reportaży,

${ }^{21}$ Cyt. za: Konrad Rokicki, Literaci. Relacje między literatami a władzami PRL w latach 1945-1970, Warszawa 2011, s. 398.

22 Dariusz Stola, Kampania antysyjonistyczna w Polsce 1967-1968, Warszawa 2000, s. 40. 
publikacji książkowych czy filmów dokumentalnych i fabularnych, które za cel stawiały sobie podtrzymanie czarnego obrazu Niemiec i Niemców"23. Stefan Kisielewski celnie zauważył w swoim dzienniku, że „Żydzi i Niemcy to dziś w socjalizmie straszak uniwersalny"24.

Antyniemiecka obsesja I Sekretarza KC PZPR przybrała radykalniejszą postać w psychozie Moczara. U autora Barw walki obydwie paranoje - antyżydowska i antyniemiecka ${ }^{25}$ - spotykały się bezkolizyjnie. „Mietek” wykazywał się szczególną bezwzględnością i brutalnością języka w atakowaniu „syjonizmu” oraz łączeniu „sprawy żydowskiej” ze zbrodniami stalinizmu i nazizmu. Do nich dochodziła, budowana na tle uznania dla wartości narodowych, wrogość wobec żydowskich komunistów przybyłych ze Związku Radzieckiego ${ }^{26}$.

Jak czytamy w komunistycznych stenogramach, w maju 1968 ,na posiedzeniu ZG ZBoWiD Moczar otwarcie mówił o »haniebnym flircie Izraela z RFN, a tym samym z Niemcami, którzy przed 25 laty posyłali Żydów do komór gazowych «"27. Wcześniej zaś (jesienią 1967 r.) w przemówieniu w Sali Kongresowej Pałacu Kultury i Nauki, w rocznicę powstania MO i SB, „Mietek” „porównał postępowanie armii Izraela w stosunku do Arabów z postępowaniem hitlerowców wobec Polaków i Żydów podczas okupacji”28.

Biograf Moczara zastanawia się nad - podnoszoną w literaturze wspomnieniowej - kwestią umocowania Biura ds. Żydów (Żydowskich) w strukturach MSW. Jakkolwiek funkcjonowanie takiej komórki nie zostało ostatecznie potwierdzone, to jednak nie da się wykluczyć jej istnienia ${ }^{29}$. Niezależnie od tego, czy istniała (formalnie albo nieformalnie), i niezależnie od odpowiedzi na pytanie o zgodność wygłaszanych w prasie antysemickich

${ }^{23}$ Zaremba, Komunizm, legitymizacja, nacjonalizm..., s. 306.

${ }^{24}$ Stefan Kisielewski, Dzienniki, Warszawa 1996, s. 121. Skalę antyniemieckich postaw i nastrojów w prozie najlepiej oddaje Raport z Monachium Andrzeja Brychta. W raporcie Germanie są ,urodzonymi mordercami”. Podobnie jak w całej propagandzie marcowej wątki wojenne, antyniemieckie, łączą się z krytyką zachodniego konsumpcjonizmu (tamtejszego stylu życia, systemu wartości). Powieści Raport z Monachium, ale też Dancing w kwaterze Hitlera są realizacją w literaturze głównych wytycznych patriotyzmu wojskowego. Andrzej Brycht, Dancing w kwaterze Hitlera. Opowiadania, Warszawa 1966.

${ }_{25}$ Bożena Szaynok, Z historia i Moskwa w tle. Polska a Izrael 1944-1968, Warszawa 2007, s. 416.

${ }_{26}$ Zob. Joanna B. Michlic, Obcy jako zagrożenie. Obraz Żyda w Polsce od roku 1880 do czasów obecnych, tłum. Anna Switzer, Warszawa 2015, s. 336.

${ }^{27}$ Krzysztof Lesiakowski, Mieczystaw Moczar „Mietek”. Biografia polityczna, Warszawa 1998, s. 337.

28 Tamże, s. 300-301.

29 Tamże, s. 294. 
treści z autentycznymi poglądami poszczególnych dziennikarzy bezdyskusyjne jest zaangażowanie Służby Bezpieczeństwa w kampanię „,antysyjonistyczną". Wpływ policji politycznej można rozpatrywać w co najmniej trzech wymiarach: dostarczaniu materiałów do publikacji, inspirowaniu tematów i strategii perswazyjnych, kontroli informacji upublicznionych $\mathrm{w}$ telewizji, radiu i na łamach gaze ${ }^{30}$.

W antysemicką nagonkę najmocniej zaangażowani byli „partyzanci” zrzeszeni w ZBoWiD pod przewodnictwem (od 1964 r.) gen. Mieczysława Moczara. W zbowidowskim piśmie „Za Wolność i Lud” działania izraelskiej armii po wybuchu wojny sześciodniowej porównano do ofensywy wojsk hitlerowskich. Pisze Waldemar Sęczyk:

Starano się skojarzyć go [Izrael] przede wszystkim z III Rzeszą. Najmocniej podkreślono ten związek w tekście Kto jest patriotą? Zdaniem Wojciechowskiego syjonizm to „teoria »narodu wybranego«, nowego »Herrenvolku«, dla którego potrzebny jest Lebensraum nad Jordanem i Gazą" ${ }^{\text {”1 }}$.

W podobnym duchu jak Kazimierz Wojciechowski na łamach „Głosu Nauczycielskiego" w radiu i prasie niejednokrotnie insynuowano, że w działania armii izraelskiej zaangażowani są potomkowie zbrodniarzy hitlerowskich. Przekonywał do tego Kazimierz Rusinek w czasopiśmie „Za Wolność i Lud”, dowodząc, ,że w armii izraelskiej zostało zaangażowane w charakterze dowódców około tysiąca zbrodniarzy nazistowskich i SS"32.

Do obligatoryjnego w wypowiedziach polityków oraz publicystów obrazu Izraela nawiązywali historycy. Wydana w 25. rocznicę powstania w getcie (i kilkakrotnie wznawiana) broszura Wacława Poterańskiego Warszawskie getto zawiera wszystkie schematy myślenia obecne w moczarowskiej propagandzie ${ }^{33}$. Wydobywa zatem na pierwszy plan kolaborujący charakter Judenratów i ,żydowskiej policji” oraz brak solidarności narodowej (cierpią przede wszystkim biedniejsi i słabsi). Poterański, tak jak publicyści marcowi, konfrontuje bierność osadzonych w getcie Żydów z obrazami Polaków - odważnych, niosących pomoc. Polscy sąsiedzi nie tylko pomagają, ale wykonują też wyroki śmierci na szmalcownikach - wyrzutkach społecznych plamiących dobre imię Polski.

${ }^{30}$ Zob. Waldemar Sęczyk, Marzec '68 w publicystyce PRL. Studium z dziejów propagan$d y$, Wałbrzych 2009, s. 246.

31 Tamże, s. 147.

${ }^{32}$ Lesiakowski, Mieczystaw Moczar „Mietek”..., s. 295.

33 Wacław Poterański, Warszawskie getto, Warszawa 1968. 
Poterański rozkłada akcenty zgodnie z oficjalną linią polityczną. Postrzega organizacje lewicowe i komunistyczne jako inicjatorów oraz głównych wykonawców antyhitlerowskiego oporu w Polsce ${ }^{34}$. Tragiczny los Żydów zaś to dzieło zachodniego imperializmu, stosunków klasowych, w których rolę prymarną odegrały burżuazja i mieszczaństwo, a wyzwolone przez komunizm siły postępu przyniosły wolność uciskanym narodom (w tym ciemiężonemu przez niemieckich faszystów narodowi żydowskiemu). W wykładni Poterańskiego żydowscy działacze lewicowi mają swoich wewnętrznych wrogów (a przynajmniej ideowych przeciwników). Są nimi bankierzy i burżuazja. Warszawskie getto to pochwała prawdziwych patriotów i żołnierzy - członków Bundu oraz Żydowskiej Organizacji Bojowej.

Do najobrzydliwszych aspektów marcowej propagandy należało dzielenie Żydów na „,dobrych” i „złych”, „swoich” i „obcych”. W publicystyce PRL klucz jest prosty: dobrzy Żydzi są biedni, wywodzą się z proletariackich rodzin, uczuciowo związanych z Polską, źli - to burżuje, kosmopolici, wrogowie ustroju socjalistycznego lub po prostu syjoniści. Znamienne, że dobrzy Żydzi - jak rodzina Altmanów w Gtupiej sprawie Stanisława Ryszarda Dobrowolskiego - giną w płomieniach Zagłady ${ }^{35}$. Dobrzy Żydzi potrafią docenić poniesiony przez społeczeństwo polskie trud ratowania przed nazistowską polityką eksterminacji. Źli nie tylko nie czują wdzięczności, ale starają się umniejszyć udział hitlerowców w zbrodniach, zrzucając winę na polskich sąsiadów.

Motyw miłosiernego Polaka i niewdzięcznego Żyda, rewanżującego się za okazaną pomoc paktowaniem $\mathrm{z}$ hitlerowcami oraz ich potomkami uczestniczącymi aktywnie w antypolskiej kampanii w zachodniej Europie, należy do obligatoryjnych w „marcowych fabułach” ${ }^{36}$. Za poświęcenie i wsparcie Żydzi odpłacali się Polakom rozpowszechnianymi na Zachodzie posądzeniami o antysemityzm. Syjoniści z ochotą uczestniczą w wybielaniu niegdysiejszych katów, a całą ich winę przypisują ofiarom - Polakom. Polscy obywatele są zatem ofiarami w podwójnym znaczeniu - jako część faszystowskiej polityki eksterminacji oraz niemiecko-żydowskiego przemysłu kłamstwa. Tym samym temat niewdzięczności ocalonych przechodzi w kolejny - podwójnie niezasłużonej winy Polaków. Prezes i „partyzanci”

${ }^{34}$ Zob. tamże, s. 9.

35 Stanisław Ryszard Dobrowolski, Ghupia sprawa, Warszawa 1969.

${ }^{36}$ Michał Głowiński, Marcowe fabuly (Rzecz o propagandzie roku 1968), [w:] tenże, Pismak 1863 i inne szkice o różnych brzydkich rzeczach, Warszawa 1995. 
ZBoWiD twierdzili, że w efekcie zawartego przez Izrael z RFN układu o odszkodowaniach rząd izraelski „usiłował usprawiedliwić Niemców za popełnione zbrodnie na Żydach, czyniąc współwinnymi Polaków”37.

Inną - oprócz poczucia krzywdy i obrazu niewdzięcznych Żydów - najczęściej podnoszoną kwestią w piśmiennictwie i publicystyce marcowej są na różne sposoby wydobywane analogie między postawą rządu Izraela a okupacją hitlerowską w Polsce. Szaleństwo antyizraelskiej propagandy sięgało zenitu, ocierało się o absurd i karykaturę:

W jednym ze swoich radiowych wystąpień działacz ZBoWiD-u, a zarazem ówczesny wiceminister kultury Kazimierz Rusinek mówił np., iż „nie jest tajemnicą, że wielu zbrodniarzy hitlerowskich jest w służbie rządu izraelskiego”. Dziennikarz „Głosu Robotniczego" Piotr Goszczyński wskazywał, iż Mosze Dajan to tak naprawdę Otto Skorzenny, „znany specjalista od morderstw i porwań z SS”. Natomiast publicystka miesięcznika „Kultura” sugerowała, że Yael Dajan, córka izraelskiego ministra obrony Mosze Dajana, [...] przypomina „osławioną Elsę Koch”, wojenną zbrodniarkę, która używała ponoć abażurów wykonanych ze skóry pomordowanych Żydów ${ }^{38}$.

Najbardziej znanym w tym czasie teoretykiem związków Izraela i RFN był Tadeusz Walichnowski, konsekwentnie udowadniający w swoich publikacjach, że porozumienie izraelsko-niemieckie wymierzone jest w kraje arabskie oraz socjalistyczne ${ }^{39}$. Mniej znanym i rzadziej przywoływanym jest Wojciech Giełżyński ${ }^{40}$. Ten popularny dziennikarz utarte zarzuty o współpracy izraelskiego rządu z RFN wymierzone w Polskę Ludową uzupełniał oskarżeniami przeciwko zachodniej prasie, która nie informuje o przykładach i skali kolaboracji Żydów z hitlerowcami ${ }^{41}$.

\section{Płaszczyzny przenikania: niepokojąca karykatura}

W Rachunku za Marzec Henryk Grynberg nazywa zajścia antyżydowskie z lat 1967-1968 „bękartem hitleryzmu”"2. „Bękartem”, a więc czymś „gorszym”, jakimś nieudanym tworem, epigońskim nawrotem. To zatem nie kopia, ale karykatura. Tym jednak dotkliwsza, że realizowana po Szoah. I to jest perspektywa, z której należy patrzeć zarówno na publicystów, jak

${ }^{37}$ Lesiakowski, Mieczystaw Moczar „Mietek”..., s. 337.

${ }^{38}$ Piotr Forecki, Od „Shoah” do „Strachu”. Spory o polsko-żydowska przeszłość i pamieć w debatach publicznych, Poznań 2010, s. 96.

39 Tadeusz Walichnowski, Izrael a NRF, wyd. 2, Warszawa 1967.

40 Wojciech Giełżński, Oko w oko z polityka, Warszawa 1969.

${ }^{41}$ Zob. Kobylarz, Walka o pamięć..., s. 186.

42 Henryk Grynberg, Rachunek za Marzec, „Wprost” (1998), nr 11. 
i artystów udzielających poparcia władzy oraz ich oceniać. Należeli do nich również rysownicy karykaturzyści ${ }^{43}$.

Agnieszka Skalska, autorka pracy o karykaturze antysemickiej, przypomina o mało znanym fakcie, jakim było zaangażowanie polskich rysowników w nagonkę antysemicką roku $1968^{44}$. Inaczej niż przedwojenna z lat trzydziestych XX w. publicystyka marcowa z okresu 1967-1968, podobnie jak karykatura tych czasów, swą wrogość wobec Żydów zasłaniała listkiem figowym - kategorią „,antysyjonizmu”. Pojęcie to z jednej strony sugerowało, że chodzi o współczesny Izrael, z drugiej uruchamiało ciąg skojarzeń z archetypicznym wręcz wyobrażeniem Żyda - tym, dla którego uformowania znacząca była m.in. tradycja endecka z okresu II Rzeczypospolitej. Jednak o odmiennym kontekście, w jakim funkcjonują dzieła Karola Baranieckiego, Eryka Lipińskiego, Zbigniewa Damskiego, Stefana Wielgusa, Jerzego Zaruby czy Edmunda Mańczaka w porównaniu z antysemickimi artykułami doby międzywojnia, decyduje nowy element, który nieuchronnie wnosi Zagłada. To, co przed nią mogło być postrzegane jako „niestosowne” żarty, po Szoah nabiera innego, upiornego charakteru. Jeśli niepomni na to Zaruba czy Damski w swoich rysunkach wprost odwołują się do ikonografii nazistowskiej, to rodzi się pytanie o rozmiary artystycznego cynizmu i koniunkturalizmu.

Szerzenie antysemityzmu było podstawową funkcją rysunków prasowych z lat 1967-1969. Przez analogię do pojęcia nowomowy Skalska nazywa je nowoobrazami ${ }^{45}$, ich sens wyczerpuje się bowiem całkowicie w intencji propagandowej. Jakkolwiek nie wszystkie antysemickie rysunki w treści nawiązują do Zagłady, to - po pierwsze - jest ich wystarczająco dużo, by mówić o osobnym kierunku w karykaturze, po drugie zaś - obrazy pośrednio lub bezpośrednio odsyłające do Szoah musiały ewokować bardzo dużą dawkę emocji, mocno oddziaływać zarówno na żydowską ofiarę, jak i polskiego świadka. Nie ulega bowiem wątpliwości, że w „polskim roku 1968”, w tym jego aspekcie, który traktował o relacjach polsko-żydowskich, temat Zagłady - oprócz motywu tzw. żydokomuny - wybrzmiewał najdobitniej. Znajdował też najliczniejszą grupę odbiorców.

${ }_{43}$ Proza i poezja polska nie dała się ponieść rozpętanej przez władze fali antyżydowskiej histerii. Polscy pisarze - poza bardzo nielicznymi wyjątkami - nie wzięli udziału w kampanii antysemickiej. Zasadę tę łamią powieść Stanisława Ryszarda Dobrowolskiego (Gtupia sprawa) oraz opowiadania Romana Bratnego (zob. Roman Bratny, Dawid, syn Henryka, Abu Null, W powietrzu, [w:] tenże, Twarde ojczyzny. Opowiadania, Warszawa 1984).

${ }_{44}$ Agnieszka Skalska, Obraz wroga w antysemickich rysunkach prasowych Marca '68, Warszawa 2007, s. 43.

45 Tamże, s. 69. 
Wyraźne odesłania do Holokaustu przynosi jedna ze strategii kompromitacji wroga - zoomorfizacja, polegająca na przydawaniu Żydom postaci i cech zwierząt, zwłaszcza pająków i świń. Skutecznie wykorzystywała ją propaganda nazistowska. W procesie odczłowieczania Żydów sprowadziła ich do pozycji insektów, które powinno się tępić jako szkodników ${ }^{46}$.

Zazwyczaj dla marcowych karykaturzystów punktem wyjścia do wprowadzenia tematyki zagładowej była historia współczesnego Izraela. Ukazywano postać Adolfa Hitlera sympatyzującego z polityką tego państwa. Znajdziemy sylwetki zbrodniarzy hitlerowskich w miłosnym uścisku z ministrem spraw zagranicznych Moszem Dajanem (on sam zaś jest zawsze ucharakteryzowany na osobnika o podejrzanej konduicie i fizjonomii). W takich przypadkach chodzi nie tylko o zdyskredytowanie wroga, ale i o swoistą zamianę ról. Oto ofiarę przedstawia się jako oprawcę: ci, którzy niegdyś byli prześladowani, teraz sami podążają ścieżką dawnych prześladowców, a niekiedy wręcz zdają się prześcigać swych nauczycieli. Hitler i Eichmann nadzorują i wspierają działania izraelskie oraz doradzają Moszemu Dajanowi przy projektach wysiedleń arabskich mieszkańców Strefy Gazy. Zgodnie zaś z ogólną zasadą mówiącą, że wszystko, co może zostać z najnowszych dziejów Izraela odniesione do wojennej przeszłości, również wypędzenie Arabów z terenów palestyńskich, przyrównuje się do eksterminacji Zamojszczyzny.

Karykaturzyści marcowi chętnie budują analogię między dwoma wymownymi symbolami - gwiazdą Dawida oraz swastyką (zastępowaną niekiedy krzyżem żelaznym). Obydwa mają budzić równie odrażające skojarzenia i wywoływać takie same negatywne emocje. Podobnie - $\mathrm{z}$ awersją i uczuciem obrzydzenia - miał reagować polski czytelnik na działania izraelskich żołnierzy stale zestawianych z nazistowskimi zbrodniarzami. Karykatura stanowiła bezpośrednie dopełnienie jednego z głównych tematów artykułów prasowych. Izraelski wojskowy okazywał się pilnym uczniem i wprawnym kopistą esesmana czy gestapowca. Autorzy tego typu rysunków „posługują się tropami zaczerpniętymi z ikonografii okupacyjnej”"47.

W rysunkach marcowych spotkamy też odwieczny temat żydowskiego przekupstwa. Sugeruje się zatem, że za odszkodowania otrzymane od rządu NRF (tzw. układy luksemburskie) ocalali z Zagłady zaprzedali swych rodaków, zdradzili pamięć pomordowanych (znamienny ewangeliczny motyw judaszowych srebrników skwapliwie wykorzystany przez satyryków).

${ }^{46}$ Zob. hasło: Zwierzę, [w:] Ślady Holokaustu w imaginarium kultury polskiej, red. Justyna Kowalska-Leder i in., Warszawa 2017, s. 507-531.

${ }^{47}$ Skalska, Obraz wroga..., s. 132. 
To jeden z tematów często podejmowanych przez publicystykę tamtego czasu (w prozie znajdziemy go w Gtupiej sprawie Dobrowolskiego oraz Dawidzie, synu Henryka Bratnego).

Żyd z karykatury marcowej nie pojawia się w pejsach i chałacie, jak w europejskiej karykaturze XIX-wiecznej czy polskiej z lat 1918-1939. To wszędobylski sprzymierzeniec nazistów, ukryty faszysta. Skalska tak podsumowuje główną tematykę swojej rozprawy:

Postacie na rysunkach to Izraelczycy, wpisywani w militarne porządki znaczeniowe - to żołnierze, czołgiści, okupanci, agresorzy. Odniesieniem dla takiej ich charakterystyki najczęściej są tropy okupacyjne. Izraelczycy są więc uczniami nazistów, ich naśladowcami. Odniesienie do ikonografii II wojny światowej pozwala na konstrukcję przekazów dotyczących konotacji związanych z rolą ofiary. Izrael naśladuje faszystów, przyjmuje odszkodowania wojenne, handlując pamięcią o Zagładzie ${ }^{48}$.

Państwową politykę Izraela należało jednak powiązać z wewnętrznymi problemami PRL. Pomost wyznaczyły takie pojęcia, jak hitleryzm i okupacja.

Przedstawienia odsyłające do Holokaustu - tak w rysunkach, jak w artykułach prasowych - mają za zadanie kompromitację polskiego antysemityzmu. Jak twierdzą dyspozycyjni dziennikarze i karykaturzyści, niechęć czy wrogość do Żydów to projekt przeciwników socjalizmu i polskości służący wybieleniu niemieckich zbrodni. W procederze tym mają uczestniczyć reprezentanci żydowskiej diaspory na Zachodzie oraz politycy izraelscy. W tym duchu podsumował swój wywód autor „Trybuny Ludu”: „Socjalistyczna Polska zwalczała i będzie konsekwentnie zwalczać wszelkie objawy nacjonalizmu, nienawiści rasowej, ale także nigdy nie pozwoli szantażować się straszakiem antysemityzmu" ${ }^{49}$.

\section{Płaszczyzny przenikania: w kręgu tematów literackich}

Podobieństwo wydarzeń marcowych do Zagłady podnosili zarówno autorzy tekstów wspomnieniowych, jak i beletrystycznych. Centralnym toposem jest tu motyw DWORCA GDAŃSKIEGO - wyróżniony przez Władysława Panasa w pionierskim szkicu o topice literatury polsko-żydowskiej ${ }^{50}$.

48 Tamże, s. 278-279.

49 Cyt. za: Mieczysław Abramowicz, Każdy przynióst, co miat najlepszego, Gdańsk 2006, s. 266.

50 Zob. Władysław Panas, Topika judajska w literaturze polskiej XX wieku, [w:] tenże, Pismo i rana. Szkice o problematyce żydowskiej w literaturze polskiej, Lublin 1996, s. 140. 
DWORZEC GDAŃSKI odsyła do jednego z najtrwalszych i najłatwiej rozpoznawalnych toposów piśmiennictwa o Holokauście - POCIĄGÓW ŚMIERCI ${ }^{51}$. Stały się one znakiem tak wyrazistym i mocno zakotwiczonym w świadomości powszechnej, że wszelkie aluzje drugowojenne do kolei wywołują skojarzenia z Zagładą ${ }^{52}$. POCIĄGI ŚMIERCI w Marcu nie niosły już fizycznego unicestwienia. Były raczej znakiem pustki, jaką zostawiali po sobie emigrujący Żydzi.

Atmosfera poprzedzająca wyjazd z Polski oraz miejsce, skąd odjeżdżali żydowscy uchodźcy w Marcu '68 (dworzec znajdował się w bezpośrednim sąsiedztwie Umschlagplatzu, z którego w czasie okupacji odprawiano transporty do Treblinki), musiały budzić skojarzenia z epoką pieców. Pamięć uruchamiała wspomnienia. Marzec dotykał jej najgłębszych pokładów, aktywując obrazy wyparte, skrzętnie skrywane.

Najbardziej wyraziście analogie z Zagładą w polskiej prozie oddaje fragment z Westernu Józefa Hena. Narrator przychodzi na Dworzec Gdański: „Było kilku pijanych. Jakiś spóźniony odprowadzający, rozchełstany i spocony byk, przepychał się przez tłum wykrzykując: »Gdzie tu ten pociąg do Treblinki? «. Ktoś się roześmiał, ktoś z tych wyjeżdżających"53.

W Syjonistach do Syjamu Marka Nowakowskiego „koleżanka Żydówka opowiada o strachu, jaki ogarnął jej starą matkę. Obudził się atawizm prześladowań, szczególnie w kobiecie, która przeżyła Holokaust" "54. Być może pisarz nawiązuje do opisanej w tym zbiorze historii matki i córki. Pięćdziesięcioletnia kobieta, która przeżyła Zagładę, reaguje histerycznie na wiadomość o zniszczeniu nagrobków na cmentarzu żydowskim przez pijanych mężczyzn:

Dziewczyna dokładnie zrelacjonowała matce historię cmentarnego zdarzenia. Ale matki wcale to nie przekonało. Nadal te wielkie, przerażone oczy, i niepokoi ją głośniejszy tupot na schodach, głosy i śmiechy dobiegające z ulicy. Podchodzi do

${ }^{51}$ To jeden z toposów zagładowych wyróżnionych przez Sławomira Buryłę - zob. Sławomir Buryła, Topika Holokaustu. Wstępne rozpoznanie, [w:] tenże, Wokót Zagłady. Szkice o literaturze Holokaustu, Kraków 2016.

${ }^{52}$ Wojciech Tomasik, badacz obrazów kolei w literaturze i kulturze polskiej, pisze: „Jeśli pomnikiem XIX stulecia, epoki pary i elektryczności, pozostaje parowóz, to stulecie następne, przeszło do historii pod nazwą wieku totalitaryzmów, może być wyobrażone [...] w formie towarowego wagonu, którego stacją przeznaczenia był nazistowski obóz śmierci”. Wojciech Tomasik, Ikona nowoczesności. Kolej w literaturze polskiej, Wrocław 2007, s. 235.

53 Józef Hen, Western, [w:] tenże, Oko Dajana, Warszawa 1990, s. 39.

${ }^{54}$ Marek Nowakowski, Syjoniści do Syjamu. Zapiski z lat 1967-1968, Warszawa 2009, s. 207. O odradzającej się traumie z czasów Zagłady w Marcu '68 wspomina Michał Głowiński w wywiadzie udzielonym Teresie Torańskiej - zob.: Teresa Torańska, Sa. Rozmowy o dobrych uczuciach, Warszawa 2007. 
okna, nieznacznie odsuwa zasłonę i patrzy, patrzy. [...] A potem strach, irracjonalny strach przekazywany z pokolenia na pokolenie, chwycił ją za gardło ${ }^{55}$.

Zaszczuta psychika ocalonego spychała na dalszy plan prawdę o tym, że antyżydowskie wystąpienia zostały zaszczepione obywatelom PRL. Liczył się tylko strach, który ofiara pamiętała z nie tak odległej przeszłości.

Wystarczająco często i jednoznacznie dawano do zrozumienia obywatelom polskim pochodzenia żydowskiego, że nie są tu pożądani. Żydzi opuszczali Polskę z różnych powodów, ale jedno było w tym czasie wspólne wszystkim wyjeżdżającym. Ofiara w pośpiechu - podobnie jak w czasie hitlerowskiej okupacji - wyprzedawała swój dobytek. Tak jak przed rokiem 1945 za niewielkie sumy mogli go nabyć polscy sąsiedzi ${ }^{56}$.

Analogię z Holokaustem z pewnością wzmacniała też ciągle żywa i nieprzepracowana pamięć. Jej natura była gorąca, bo przecież od epoki pieców minęło zaledwie dwadzieścia kilka lat. Marzec '68 nie tylko nie dał szansy na rozmowę o trudnych problemach z przeszłości - fałszując i spychając je w sferę kłamstwa, nie stworzył też możliwości wyzwolenia się z traumy (przepracowania, mówiąc językiem współczesnych znawców tego zagadnienia), ale jeszcze dodatkowo wzmocnił postawę Polaków - obronną i agresywną zarazem. Skalska, referując ustalenia innych badaczy, wyróżnia trzy wymiary polskiej niepamięci o Zagładzie w Marcu '68: „obronę własnej reputacji”, „wypieranie wspomnień traumatycznych” oraz próbę odepchnięcia myśli o swoim współudziale w Szoah ${ }^{57}$.

\section{Płaszczyzny przenikania: pamięć ofiar}

W Marcu to umysł ocalonego generował podobieństwa do Szoah, reanimując obrazy z czasów Zagłady. Wkraczamy tym samym ponownie na teren subiektywnych odczuć ofiary - delikatnej materii pamięci indywidualnej i zbiorowej. Zagłada nie powracała w liczbach ani w stopniu doświadczonego okrucieństwa, ale w lękach, które pozostawiła w psychice ofiar, w traumie psychicznej. By właściwie uchwycić jej siłę, należy - oprócz uświadomienia sobie skali doznanych cierpień - zwrócić uwagę na inny

${ }^{55}$ Nowakowski, Syjoniści do Syjamu..., s. 16-17.

${ }^{56}$ Luiza z opowiadania Krzysztofa Kąkolewskiego stwierdza sarkastycznie: „Już szykują się, by wykupywać żydowskie samochody za grosze”. Krzysztof Kąkolewski, Nieznany przyjaciel, [w:] tenże, Szukanie Beegera. Opowiadania gojowskie, Warszawa 1993, s. 183.

57 Skalska, Obraz wroga ..., s. 191. 
fakt: ocalałym nie dano możliwości odbycia żałoby. Ponadto tłumili w sobie smutek, żal - ten główny do Niemców i ten dodatkowy do polskich sąsiadów.

Bohater Bliźniaków Józefa Hena dobrze oddaje sens tych odczuć w słowach: „Jesteśmy bardziej obrażeni niż prześladowani, bardziej wyszydzeni niż bici, bardziej opluci i odtrąceni niż spoliczkowani" ${ }^{58}$. Nie chodzi zatem o przejawy fizycznego prześladowania, lecz powracającą z lat okupacji obawę przed fizycznymi prześladowaniami. Wzmacniała ją bierność otoczenia, a niekiedy również - dający się słyszeć w miejscach pracy, na ulicy, w rozmowach znajomych i sąsiadów - obrzydliwy, antysemicki język. Antysemickie artykuły zamieszczane na łamach „Słowa Powszechnego”, „Prawa i Życia”, „Żołnierza Wolności” czy „Kuriera Polskiego” bezwiednie odsyłały myśli ocalałych do epoki pieców, reaktywowały w ich pamięci zdarzenia sprzed dwudziestu lat. U części z nich zapewne wywoływały uczucie grozy, niedowierzania, szoku. Jak wspomina jedna z przedstawicielek „pokolenia '68”, przywołując nasilającą się w mediach kampanię antysemicką: „Drugą rzeczą, która była taka niesłychanie ważna w tym całym subiektywnym obrazie, to było to, że oczywiście Żydzi zareagowali [...] lękiem holokaustowym" 59 .

Poczucie zagrożenia, niepewność dalszych losów własnych i najbliższej rodziny, narastający strach przed nieznanym wywoływały skojarzenia z Zagładą. Stymulowały je reminiscencje przedwojennej i powojennej przemocy kolektywnej wobec Żydów. Proza wielokrotnie te stany ukazywała. Znajdziemy je zarówno w tekstach powstających w bezpośrednim sąsiedztwie Marca '68 (Oko Dajana i Milczące między nami Hena), jak i tych napisanych kilkadziesiąt lat później (Ucieczka lisów z tomu pt. Włoskie szpilki Magdaleny Tulli) ${ }^{60}$. Jak stwierdza Michał Głowiński w Kręgach obcości: „U wielu odrodziły się traumy z czasów Zagłady”61.

Ofiara była przekonana, że rozmiar upokorzeń i bólu doznanego w czasie okupacji ochroni ją przed ludzką podłością. Stało się inaczej. W takich przypadkach gorycz i żal odżywały i uderzały ze zdwojonym impetem. By właściwie ocenić przywołane sądy i reakcje świadków Marca, trzeba pamiętać, że mamy do czynienia z psychiką naznaczoną traumą.

W Marcu ' 68 istotne były zatem lęki i przeczucia, a nie rzeczywista utrata zdrowia lub śmierć. Nie mieliśmy przecież do czynienia z przemocą fizyczną

58 Józef Hen, Bliźniak, [w:] tenże, Oko Dajana ..., s. 147.

59 Piotr Osęka, My, ludzie z Marca. Autoportret pokolenia '68, Wołowiec 2015, s. 324.

${ }^{60}$ Magdalena Tulli, Ucieczka lisów, [w:] taż, Włoskie szpilki, Warszawa 2011.

${ }^{61}$ Michał Głowiński, Kręgi obcości. Opowiesśc autobiograficzna, Kraków 2010, s. 332. 
ani tym bardziej ze śmiercią (choć zdarzały się przypadki samobójstw). Raczej z jej przeczuciem. Obawy przed zbliżającymi się prześladowaniami najpełniej w prozie tego czasu oddaje Msza za miasto Arras. Andrzej Szczypiorski $^{62} \mathrm{w}$ swojej najwybitniejszej książce czyni bezpośrednie aluzje do Marca '68: do dusznej atmosfery tamtych dni. Powieść wyrażała stan narastającego zagrożenia, ale też była jego pośrednim wytworem. Geneza Mszy za miasto Arras wiąże się bowiem z wydarzeniami roku 1968 (powstawała dokładnie w tamtym czasie), a Szczypiorski był bezpośrednim świadkiem antyżydowskiej nagonki.

Kwestią wymagającą osobnego szkicu jest wpływ nagonki antysemickiej z wydarzeń marcowych na wystąpienie albo nasilenie się objawów traumy zagładowej w tzw. drugim pokoleniu. To ostatni aspekt związków Zagłady i Marca '68. Kim były „marcowe dzieci”? Dorastały zazwyczaj w rodzinach, w których żydostwo i wszystko, co się z nim wiąże, stanowiło tabu. W rodzinach zasymilowanych, gdzie istniały silne związki z ideologią komunistyczną, żydostwo było kwestią drugorzędną, raczej zbytecznym balastem niż czymś znaczącym dla konstytuowania tożsamości narodowej. Inaczej było w rodzinach religijnych. I w jednych, i drugich jednak czynnikiem decydującym była Zagłada. „Psychologiczną konsekwencję Zagłady stanowił [...] ukryty lęk, którym podszyta była rodzinna atmosfera"63. Chciano odizolować dzieci od tej wiedzy. Zgodnie twierdzono, że najlepszym wyjściem jest konsekwentne chronienie potomstwa przed zetknięciem z przeszłością rodziców i dziadków ${ }^{64}$. Nie zawsze się to udawało, czasem było to niemożliwe. Często rówieśnicy w szkole brutalnie wyciągali na światło dzienne to, co było skrzętnie skrywaną tajemnicę. Niektórzy przedstawiciele drugiego pokolenia jeszcze później poznawali prawdę. Młodzi ludzie często dowiadywali się o swoim pochodzeniu z propagandy marcowej (a raczej pod jej wpływem).

W Marcu odżywały upiory, przerażające historie sprzed lat. Ich wspomnienie dotykało zarówno bezpośrednich świadków, jak i ich potomstwo. Zagłada odradzała się w podwójnym wymiarze - w świadomości rodziców i dzieci.

${ }^{62}$ Andrzej Szczypiorski, Msza za miasto Arras, Warszawa 1982.

${ }^{63}$ Osęka, My, ludzie z Marca..., s. 55.

${ }^{64}$ Joanna Wiszniewicz, Życie przecięte. Opowieści pokolenia Marca, Wołowiec 2008. 


\section{Résumé: Zagłada nieprzeżyta}

Publicystyka marcowa, w tym również powstające wtedy opracowania naukowe (popularnonaukowe) i teksty wspomnieniowe, dobitnie pokazuje, że spór o Zagładę, choć mocno był uwikłany w ówczesny kontekst społeczno-polityczny, nie pojawił się znikąd. Stanowił kontinuum zdarzeń dwudziestu powojennych lat, rezultat hipokryzji, z jaką komuniści (i społeczeństwo) podchodzili do nieodległej, wojennej przeszłości. To teza nienowa i powtarzana dość często przy dyskusjach na temat tła powojennego antysemityzmu. Już w latach osiemdziesiątych XX w. sformułował ją Aleksander Smolar:

Na Zachodzie konsekwencje antysemityzmu rasistowskiego spowodowały jednoznaczne potępienie wszelkich form antysemityzmu. [...]

Polska reakcja na Holocaust była zupełnie inna. Nie wywołał on szoku w świadomości zbiorowej Polaków. Wydarzenia wojenne i bezpośrednio powojenne wzmocniły jeszcze poczucie obcości i wrogości. [...] Doświadczenia wojny nie prowadziły do kompromitacji postaw antysemickich. W Polsce bowiem nie było żadnych związków między radykalnym nawet antysemityzmem narodowej prawicy a antysemityzmem niemieckim. Przeciwnie, doświadczenia wojenne i powojenne wzmacniały patriotyczną prawomocność uczuć antyżydowskich ${ }^{65}$.

Skala ofiar i cierpień narodu polskiego w czasie wojny stanowiła po wojnie okoliczność sprzyjającą wzmocnieniu postaw antyżydowskich przy jednoczesnym „umniejszaniu wagi eksterminacji Żydów”66. Dodatkowo propaganda antyżydowska prowadzona w czasie okupacji przez hitlerowców, a przede wszystkim moralna deprawacja, jaką niosła ze sobą rzeczywistość wojenna, skutkowały pogłębieniem istniejących uprzedzeń i unieważnieniem kontekstu zagładowego. Niemożność wypowiedzenia w pełni własnego bólu przez Polaków (Katyń, rzeź na Wołyniu, powstanie warszawskie), ale i pamięć o własnej winie wobec Żydów - wszystko wzmagało antyżydowski resentyment ${ }^{67}$. Tworzyło nastrój, w którym nietrudno było rozpalić iskrę wrogości.

${ }^{65}$ Aleksander Smolar, Tabu i niewinność, „Aneks” (1986), nr 41-42, s. 127.

${ }_{66}$ Tamże.

${ }^{67}$ Jan Józef Lipski w Kwestii żydowskiej tłumaczył, iż „frazeologia patriotyczna, która miała wszelkie szanse dobrego odbioru z bardzo prostego powodu: w tym kraju przez dziesiątki lat obrażano godność narodową Polaków przez fałszowanie historii, przez usiłowanie zhańbienia spraw, które dla nas wszystkich były bardzo drogie i w których moje pokolenie brało czynny udział. Fałszowano historię wojny, przedstawiano w fałszywym świetle obraz II Rzeczypospolitej, września 1939 r., walk polskiego żołnierza na Zachodzie, AK, Batalionów Chłopskich, Powstania Warszawskiego itd. Wytworzyła się w świadomości sytuacja, 
Przemilczana (niewypowiedziana) świadomość niemieckich zbrodni przeciwko narodowi żydowskiemu wiązała się z koniecznością nieujawniania własnych ran. Smolar nie pisze wprost, dlaczego wojna i czas tużpowojenny utwierdziły, a nawet spotęgowały antyżydowskie nastroje. Dziś wiemy, że kryło się za tym m.in. niewypowiedziane poczucie winy za obojętność wobec żydowskiego losu w czasach okupacji, a niekiedy nawet i współudział w zbrodni (bezpośrednio lub poprzez falę donosów). To niezwerbalizowane i nierozpoznane podejrzenie dotyczące własnej winy (wynikające zarówno z biernego świadkowania, jak i niekiedy uczestnictwa w Endlösung) jest zjawiskiem szczególnie interesującym i ważnym w spotkaniu Marca i Zagłady: dobrze oddaje to literatura najnowsza, w której pamięć Marca jest jednocześnie pamięcią Holokaustu ${ }^{68}$.

Feliks Tych postrzega Marzec jako rezultat zakamuflowania stosunków polsko-żydowskich z okresu II wojny światowej, traktowania ich jako tabu. Stworzoną przez badacza formułę , długiego cienia Zagłady” można więc odnieść do wydarzeń marcowych ${ }^{69}$. Wszak w trakcie antyżydowskiej nagonki żyły jeszcze miliony ludzi, którzy byli świadkami lub nosicielami antysemityzmu lat trzydziestych $\mathrm{XX} \mathrm{w.}{ }^{70}$

Badacz ten, zastanawiając się na źródłami poparcia dla antysemickiej kampanii, stwierdza: „Najkrótszą odpowiedzią na to pytanie jest przypomnienie, że zdecydowana większość Polaków nie opłakiwała zamordowanych Żydów"71. Kategoryczna konstatacja Tycha - choć prawdziwa - domaga się jednak krótkiego dopowiedzenia: w dużym stopniu szansy na przeżycie żałoby nie dali komuniści, a pamięć o własnym cierpieniu skutecznie przesłaniała pamięć o cierpieniu innych. Zaraz po klęsce hitleryzmu Maria Kann pisała o nierozwiązanych stosunkach polsko-żydowskich jak o „powracającej fali”’². Dwadzieścia kilka lat po wojnie fala antysemityzmu

która dawała poważne szanse każdemu, kto odwoła się do frazeologii patriotycznej, że to, co głosi, zostanie bezkrytycznie uchwycone wraz z tym, co do tego uda się dobudować zręcznym propagandystom”. Jan Józef Lipski, Kwestia żydowska, [w:] Marzec '68. Referaty z sesji na Uniwersytecie Warszawskim w 1981 roku, Warszawa 2008, s. 153.

${ }_{68}$ Zob. na ten temat: Anna Artwińska, „Odrodzity się traumy z czasów Zagłady”. Marzec 1968 jako narracja postkatastroficzna, „Poznańskie Studia Polonistyczne” (2015), nr 25.

${ }^{69}$ Zob. Feliks Tych, Długi cień Zagłady. Szkice historyczne, Warszawa 1999.

${ }^{70}$ Feliks Tych, „Marzec '68”. Geneza, przebieg i skutki kampanii antysemickiej lat 1967/68, [w:] Nastęstwa zagłady Żydów. Polska 1944-2010, red. Feliks Tych, Monika Adamczyk-Garbowska, Lublin 2011, s. 391.

71 Tamże, s. 390.

72 Maria Kann, Martwa fala, [w:] Martwa fala. Zbiór artykułów o antysemityzmie, oprac. Stanisław Ryszard Dobrowolski, Warszawa 1947. 
nie wezbrała jednak samoistnie. Była skalkulowanym efektem zabiegów władzy komunistycznej w Polsce 1968 roku.

\section{Bibliografia}

\section{1. Źródła opublikowane}

Abramowicz Mieczysław, Każdy przynióst, co miat najlepszego, Gdańsk 2006.

Bratny Roman, Dawid, syn Henryka, Abu Null, W powietrzu, [w:] tenże, Twarde ojczyzny. Opowiadania, Warszawa 1984.

Brycht Andrzej, Dancing w kwaterze Hitlera. Opowiadania, Warszawa 1966.

Brycht Andrzej, Raport z Monachium, wyd. 3, Warszawa 1968.

Dobrowolski Stanisław Ryszard, Gtupia sprawa, Warszawa 1969.

Giełżyński Wojciech, Oko w oko z polityka, Warszawa 1969.

Głowiński Michał, Kręgi obcości. Opowieść autobiograficzna, Kraków 2010.

Grynberg Henryk, Memorbuch, Warszawa 2000.

Hen Józef, Oko Dajana, Warszawa 1990.

Kann Maria, Martwa fala, [w:] Martwa fala. Zbiór artykułów o antysemityzmie, oprac.

Stanisław Ryszard Dobrowolski, Warszawa 1947.

Kąkolewski Krzysztof, Nieznany przyjaciel, [w:] tenże, Szukanie Beegera. Opowiadania gojowskie, Warszawa 1993.

Kisielewski Stefan, Dzienniki, Warszawa 1996.

Nowakowski Marek, Syjoniści do Syjamu. Zapiski z lat 1967-1968, Warszawa 2009.

Poterański Wacław, Warszawskie getto, Warszawa 1968.

Szczypiorski Andrzej, Msza za miasto Arras, Warszawa 1982.

Torańska Teresa, Są. Rozmowy o dobrych uczuciach, Warszawa 2007.

Tulli Magdalena, Ucieczka lisów, [w:] taż, Włoskie szpilki, Warszawa 2011.

Walichnowski Tadeusz, Izrael a NRF, wyd. 2, Warszawa 1967.

Wiszniewicz Joanna, Życie przecięte. Opowieści pokolenia Marca, Wołowiec 2008.

Załuski Zbigniew, Przepustka do historii, Warszawa 1963.

Załuski Zbigniew, Siedem polskich grzechów głównych, Warszawa 1962.

\section{Opracowania}

Adamczyk-Garbowska Monika, Duda Henryk, Terminy „Holocaust”, „Zagłada”, „Szoa” oraz ich konotacje leksykalno-kulturowe w polszczyźnie potocznej i dyskursie naukowym, „Pro Memoria” (2007), nr 25.

Artwińska Anna, ,Odrodziły się traumy z czasów Zagłady”. Marzec 1968 jako narracja postkatastroficzna, „Poznańskie Studia Polonistyczne” (2015), nr 25.

Buryła Sławomir, Topika Holokaustu. Wstępne rozpoznanie, [w:] tenże, Wokót Zagłady. Szkice o literaturze Holokaustu, Kraków 2016.

Eisler Jerzy, Polski rok 1968, Warszawa 2006.

Forecki Piotr, Od „Shoah” do „Strachu”. Spory o polsko-żydowska przeszłość i pamięć $w$ debatach publicznych, Poznań 2010. 
Friszke Andrzej, Przystosowanie i opór. Studia z dziejów PRL, Warszawa 2007.

Głowiński Michał, Marcowe fabuly (Rzecz o propagandzie roku 1968), [w:] tenże, Pismak 1863 i inne szkice o różnych brzydkich rzeczach, Warszawa 1995.

Grynberg Henryk, Rachunek za Marzec, „Wprost” (1998), nr 11.

Jarosz Anna Barbara, Marzec w prasie, [w:] Marzec 1968. Trzydzieści lat później. T. 1: Referaty, red. Marcin Kula, Piotr Osęka, Marcin Zaremba, Warszawa 1998.

Kobylarz Renata, Walka o pamięć. Polityczne aspekty obchodów rocznicy powstania w getcie warszawskim 1944-1989, Warszawa 2009.

Lesiakowski Krzysztof, Mieczystaw Moczar „Mietek”. Biografia polityczna, Warszawa 1998.

Lipski Jan Józef, Kwestia żydowska, [w:] Marzec '68. Referaty z sesji na Uniwersytecie Warszawskim w 1981 roku, Warszawa 2008.

Lubelski Tadeusz, Historia kina polskiego. Twórcy, filmy, konteksty, Katowice 2009.

Michlic Joanna B., Obcy jako zagrożenie. Obraz Żyda w Polsce od roku 1880 do czasów obecnych, tłum. Anna Switzer, Warszawa 2015.

Osęka Piotr, Marzec '68, Kraków 2008.

Osęka Piotr, My, ludzie z Marca. Autoportret pokolenia '68, Wołowiec 2015.

Panas Władysław, Topika judajska w literaturze polskiej XX wieku, [w:] tenże, Pismo i rana. Szkice o problematyce żydowskiej w literaturze polskiej, Lublin 1996.

Polniak Łukasz, Patriotyzm wojskowy w PRL w latach 1956-1970, Warszawa 2011.

Rokicki Konrad, Literaci. Relacje między literatami a władzami PRL w latach 1945-1970, Warszawa 2011.

Rutkowski Tadeusz P., Adam Bromberg $i$ „encyklopedyści”. Kartka z dziejów inteligencji w PRL, Warszawa 2010.

Sęczyk Waldemar, Marzec '68 w publicystyce PRL. Studium z dziejów propagandy, Wałbrzych 2009.

Siwiński Ireneusz, „Barwy walki” albo tęsknota za legenda, [w:] Syndrom konformizmu? Kino polskie lat sześćdziesiatych, red. Tadeusz Miczka, Alina Madej, Katowice 1994.

Skalska Agnieszka, Obraz wroga w antysemickich rysunkach prasowych Marca '68, Warszawa 2007.

Smolar Aleksander, Tabu i niewinność, „Aneks” (1986), nr 41-42.

Stola Dariusz, Kampania antysyjonistyczna w Polsce 1967-1968, Warszawa 2000.

Szaynok Bożena, Z historia i Moskwa w tle. Polska a Izrael 1944-1968, Warszawa 2007.

Ślady Holokaustu w imaginarium kultury polskiej, red. Justyna Kowalska-Leder i in., Warszawa 2017.

Tomasik Wojciech, Ikona nowoczesności. Kolej w literaturze polskiej, Wrocław 2007. Tych Feliks, Długi cień Zagłady. Szkice historyczne, Warszawa 1999.

Tych Feliks, „Marzec '68”. Geneza, przebieg i skutki kampanii antysemickiej lat 1967/68, [w:] Nastęstwa zagłady Żydów. Polska 1944-2010, red. Feliks Tych, Monika Adamczyk-Garbowska, Lublin 2011.

Wóycicka Zofia, Przerwana żałoba. Polskie spory wokót pamięci nazistowskich obozów koncentracyjnych i zagłady 1944-1950, Warszawa 2009. 
Zaremba Marcin, Komunizm, legitymizacja, nacjonalizm. Nacjonalistyczna legitymizacja władzy komunistycznej w Polsce, Warszawa 2005.

Zwierzchowski Piotr, Kino nowej pamięci. Obraz II wojny światowej w kinie polskim lat 60., Bydgoszcz 2013.

Stawomir Buryta

Uniwersytet Warszawski s.buryla@uw.edu.pl 